\title{
Veseátültetések a szombathelyi nefrológiai centrumban, 1976-2016
}

\author{
Dobos András dr. ${ }^{1,2}$ - Ruzsa Erzsébet dr. ${ }^{2}$ - Molnár Erzsébet ${ }^{2}$ \\ Szakács Gyuláné ${ }^{2}$ - Kulcsár Imre dr. ${ }^{1,2}$
}

${ }^{1}$ Markusovszky Egyetemi Oktatókórház, Általános és Belgyógyászati Osztály, Nefrológiai Részleg, Szombathely ${ }^{2}$ B. Braun Avitum Hungary Zrt. 6. sz. Dialíziscentruma, Szombathely

\begin{abstract}
Bevezetés: Szervezett nefrológiai ellátás Szombathelyen 1976 óta múködik.
Célkitüzés: Centrumunkból vesetranszplantációra kerülő betegeink sorsának követése.

Módszer: Helyi és országos adatbázisok használata.

Eredmények: 1976-2016 között 213 betegünknél 240 vesetranszplantáció történt: hét preemptív és 206 dializált páciensnél. Élődonoros transzplantáció 11 volt. 1976-1995 között 69, 1996-2015 között 163 transzplantáció történt. A transzplantált betegek közül jelenleg is él 122 fö (túlélésük vesepótló kezelésben átlagosan 11,4 év), hétnél az átültetés 1976-1995 között történt. A leghosszabb túlélés 35,1 év volt. A vesepótló kezelésben részesülő betegek prevalenciája megyénkben 2016 végén 1367 fo/egymillió lakos volt - 32,5\%-uk beültetett vesével él.

Következtetés: Az utóbbi évtizedben transzplantált betegeink száma nőtt, azonban minimális volt az élődonoros átültetés.

Orv Hetil. 2017; 158(25): 984-991.
\end{abstract}

Kulcsszavak: krónikus vesebetegség, vesetranszplantáció, túlélés, élőszerves donáció

\section{Renal transplantations in the Centre for Nephrology in Szombathely, 1976-2016}

Introduction: The organized nephrological care in Szombathely commenced its activities in 1976. Aim: Follow-up of our patients who has undergone a kidney transplantation.

Method: We used the local and national databases.

Results: 213 patients ( 7 preemptive, 206 dialyzed) had 240 renal transplantations. Only 11 of them were living organ donation. Between 69 transplantations $(\mathrm{Tx})$ were carried out between 1976-1995, and 163 Tx were done in the second 20 years. 122 patients $(57 \%)$ are still alive (the average survival of these patients in renal replacement therapy - RRT - are 11.4 years), and 7 of them had transplantation between 1976-1995. The longest survival time was 35.1 years. Prevalence of patients on RRT at the end of 2016 was 1367 pmp in our county $(32.5 \%$ living with functioning graft).

Conclusions: Number of transplanted patients has grown in the last decade. Proportion of living organ donation was minimal.

Keywords: chronic kidney disease, renal transplantation, survival, living donor transplantation

Dobos A, Ruzsa E, Molnár E, Szakács Gy, Kulcsár I. [Renal transplantations from the Centre for Nephrology in Szombathely, 1976-2016]. Orv Hetil. 2017; 158(25): 984-991.

(Beérkezett: 2017. április 10.; elfogadva: 2017. május 4.)

\section{Rövidítések}

$\mathrm{CKD}=($ chronic kidney disease $)$ krónikus vesebetegség; eGFR = (estimated GFR) becsült glomerularis filtrációs ráta; ERAEDTA $=($ European Renal Association - European Dialysis and Transplant Association) Európai Vesebetegségek Társasága -
Európai Dialízis és Transzplantációs Társaság; GFR = glomerularis filtrációs ráta; $\mathrm{HD}=$ hemodialízis; $\mathrm{HDF}=$ hemodiafiltráció; $\mathrm{KSH}=$ Központi Statisztikai Hivatal; MANET = Magyar Nefrológiai Társaság; OVSZ = Országos Vérellátó Szolgálat; $\mathrm{PD}=$ peritonealis dialízis; $\mathrm{pmp}=($ per million people $)$ ezer $\mathrm{em}-$ 
berből; RRT = (renal replacement therapy) vesepótló kezelés, amely magában foglalja a dialízismodalitásokat és a transzplantációt egyaránt; $\mathrm{Tx}_{\mathrm{x}}=$ transzplantáció; USRDS $=($ United States Renal Data Systems) az Amerikai Egyesült Államok vesebetegségekról szóló adatbázisa

Idült vesebetegség (chronic kidney disease - CKD) alatt a vese mindazon strukturális vagy funkcionális eltéréseit értjük, amelyek három hónapnál hosszabb ideje fennállnak és hatásuk van az egyén egészségére. Osztályozása az alapbetegség, valamint a glomerularis filtrációs ráta (GFR) és a fehérjevizelés (proteinuria vagy albuminuria) mértékén alapszik [1, 2]. 2009 óta a CKD-EPI vizsgálat képlete alapján becsüljük a glomerularis filtrációs rátát [3]. Enyhén csökkent $\left(>60 \mathrm{ml} / \mathrm{min} / 1,73 \mathrm{~m}^{2}\right)$ vagy normális GFR-érték esetén vizeletvizsgálattal, szövettani vagy képalkotó vizsgálattal észlelt vese-rendellenesség esetén állapíthatunk meg CKD-t, ilyen esetekben leggyakrabban ezt a fehérjevizelés jelzi. A veseátültetett beteg kóros GFR- és vizeleteltérés hiányában is idült vesebetegnek tartandó, ezt a betegek az általános populációhoz képest nagyobb halálozása és veseszövődménygyakorisága, speciális gondozási igénye is indokolja $[1,2]$.

Az idült vesebetegség világszerte igen jelentős népegészségügyi problémává vált, amely a fejlett országokban a népesség 10-14\%-át érinti [4]. Az Amerikai Egyesült Államok felnőtt népességének 6,7\%-ában a GFR $<60 \mathrm{ml} / \mathrm{min} / 1,73 \mathrm{~m}^{2}, 13,6 \%$-a krónikus vesebeteg [5]. $\mathrm{Az}$ idült vesebetegek több mint felében a GFR $60 \mathrm{ml} /$ perc alatti, de alig 1-2\%-uk tartozik a legsúlyosabb, végstádiumú veseelégtelen csoportba. Ennek oka a jelentősen felgyorsult atherosclerosis, amely miatt a betegek többsége meghal, mielőtt még a vesepótló kezelés szükségessé válna [1, 2]. Ennek fontosságára hívja fel a figyelmet az a tény is, hogy a VI. Magyar cardiovaszkuláris Konszenzus Konferencia 2014-ben az igen magas cardiovascularis rizikócsoportba sorolta a krónikus vesebetegeket, ha az eGFR $<30 \mathrm{ml} / \mathrm{min} / 1,73 \mathrm{~m}^{2}$ és proteinuria áll fenn, de nagy kockázatúnak ítéli meg azt a vesebeteget is, akinél az eGFR 30-60 ml/min/1,73 m² és/vagy proteinuria mutatható ki [6].

Magyarországon a krónikus vesebetegek száma növekszik. Mai becslések szerint a populáció körülbelül 10\%-a szenved idült vesebetegség valamelyik stádiumában („csendes járvány”). Különösen időskorban gyakori a krónikus vesebetegség, metaanalízisek szerint a 65 év felettiek 23,4-35,8\%-át érinti. Magyarországon nincsenek pontos adataink a CKD prevalenciájáról, becslések alapján a számuk legalább 700 ezer fő, de valószínúleg ennél is több. A magyar kórházak nefrológiai szakambulanciáján gondozott vesebetegek száma 1991-ben valamivel meghaladta a 10000 fót, 2001-ben a 30000 -et, 2011ben a 70 000-et [7]. Az irodalmi adatok szerint 2013 végén a vesepótló kezelésre kerülő végstádiumú vesebetegek prevalenciája egymillió lakosra számítva Tajvanon volt a legmagasabb (3170), Japánban 2620, az Amerikai Egyesült Államokban 2080, az EU 28 országának átlagában 1090 (legmagasabb Portugáliában: 1410) [5, 8, 9]. A magyarországi prevalencia 900 feletti volt. Magyarországon az összes dializált beteg száma az elmúlt három évben nem mutatott lényeges változást (2014ben 11 815, 2015-ben 11 743, 2016-ban 11736 beteget kezeltek). Az incidens dializált betegek száma 2016ban 4805 volt, a prevalens betegek száma év végén 6456 volt (közülük 5595-öt hemodialízissel kezeltek, 861-et peritonealisan dializáltak) $[10,11]$.

A betegség progressziója során elérhet a végstádiumú vesebetegséghez, amikor vesepótló kezelésre van szükség. Mind a dialíziskezelés, mind a vesetranszplantáció biztosítja a beteg túlélését, de a teljes rehabilitáció elérhetősége, a jobb életminőség és a hosszabb távú túlélés a veseátültetés mellett szól. Az ERA-EDTA regiszter adatai alapján a dializáltak ötéves túlélése 41,5\% (rosszabb számos malignoma túlélésénél), a cadaver donoros veseátültetettek ötéves túlélése $87,9 \%$, az élődonoros transzplantáltaké 94,2\% [9]. A vesetranszplantáció nemcsak szabadabb életformát biztosít, hanem szerencsés, ideális esetben a vesefunkció normalizálásával az urémiás toxinok teljesen eltûnnek. Ennek köszönhető, hogy a transzplantált betegek halálozása „csak” 1,3-1,6-szerese, míg a dializáltaké 6,7-8,5-szerese az azonos életkorú átlagpopulációénak [12]. Megkülönböztetünk cadaver donorból származó szervvel történt veseátültetést és élő szerves donációt. A recipiens nem feltétlenül dializált: lehet súlyos krónikus veseelégtelenségben vagy predialízis stádiumban levő személy is (úgynevezett preemptív transzplantáció esetén) [13].

Magyarországon az első sikeres veseátültetést Németh András végezte 1962-ben Szegeden, élőszerves donáció és egésztest-besugárzás keretében (ez volt a világon közölt 38. veseátültetés) - a páciens 79 nappal élte túl a mütétet [14-16]. 1968-ban szintén Szegeden történt az első cadaver szerves veseátültetés. Nagyobb sorozatot operáltak Pintér és mtsai Miskolcon 1975-ben [16]. Szervezett formában 1973-ban Budapesten kezdődött a vesetranszplantációs program az első sikeres cadavervese-átültetéssel (1973. november 16-án Perner Ferenc és mtsai). 1973-ban rögtön hat veseátültetés történt [17]. 1979-ben csatlakozott második vesetranszplantációs centrumként Szeged, majd 1991-ben Debrecen, végül 1993-ban Pécs is. Magyarországon 2016 végéig az OVSZ adatai szerint 7988 veseátültetés történt. A legsikeresebb évben, 2012-ben 390 főnél, tavaly pedig 343 esetben transzplantáltak vesét a négy centrumban [18].

Szombathelyen 1976-ban indult a nefrológiai szakellátás, járó- és fekvőbeteg-ellátással. Ugyanebben az évben már megtörtént az első Vas megyei vesebeteg transzplantációja is. Az első két vesetranszplantált páciensünk még nem nálunk részesült dialízisben, de Szombathelyen történt a nefrológiai gondozásuk.

A krónikus dialízisprogram 1978 óta létezik Szombathelyen, de ekkor még csak kórházi intermittáló perito- 


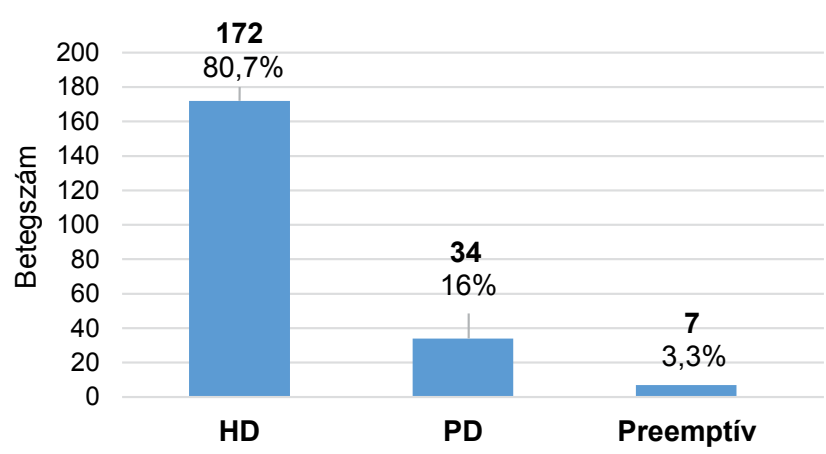

1. ábra

Az első transzplantáció elótti vesepótló modalitások megoszlása és preemptív transzplantációk $(\mathrm{n}=213)$

nealis dialízis volt elérhető nálunk. Hemodialízist 1983 óta végzünk, eleinte több megyéből is érkeztek betegeink, 1989 óta azonban csak Vas megyei betegek tartoznak hozzánk.

\section{A vizsgálat tárgya}

Célunk a vesetranszplantáción átesett betegeink sorsának követése volt. Magyarországon poszttranszplantációs nefrológiai gondozás a transzplantációs klinikákon és osztályokon zajlik, ezért a transzplantáltak kiesnek a helyi nefrológiai ellátás látóköréból. Emiatt nagyon nehéz a további sorsuk alakulását vizsgálni, ehhez szívós kutatómunka szükséges - és egységes adatbázis hiányában nem is tudtunk minden betegről fontos információkat beszerezni.

\section{Módszer}

Az adatgyưjtés a Markusovszky Egyetemi Oktatókórház kezdeti papíralapú járóbeteg-dokumentációjából, később a kórházi járó- és fekvőbeteg számítógépes adatbázisból (MedSol), a dialízisszolgáltatóktól (B.Braun Avitum Zrt. - NEPHRO7), a betegeink ellátásában szerepet játszó transzplantációs központoktól, illetve az Országos Vérellátó Szolgálattól történt. Munkánkban nagy segítséget nyújtott a Vas Megyei Vesebetegekért Egyesület is.

\section{Betegek}

1976-2016 között, a vizsgált 41 évben 213 betegünknél 240 veseátülttetés (Tx) történt. A transzplantációk 97,1\%-át Budapesten végezték (233 esetben), a többi Pécsett (hat esetben) és Szegeden (egy fönél) történt.

A vizsgált időszakban nyolc technikailag sikertelen vesetranszplantációnk volt $(3,3 \%)$.

\section{Eredmények}

Transzplantált betegeink nemek szerinti megoszlását vizsgálva férfi túlsúlyt tapasztaltunk (140 férfi vs. 73 nő). A transzplantáció előtti vesepótló modalitásokat illetően (1. ábra) a hemodializáltak voltak többségben (172 fó, $80,7 \%$ ) a peritonealisan dialízisből érkezőkkel (34 fó, $16 \%)$ szemben, hét betegünk $(3,3 \%)$ korábban nem részesült vesepótló kezelésben, hanem úgynevezett preemptív vesetranszplantáció történt. Az élőszerves donáció aránya a vizsgált 40 évben 4,6\% volt, ami 11 esetet jelent. Öten az 1980-as években kaptak élődonortól szervet. A 2. ábrán látható, hogy alakultak a sikeres vesetranszplantációk 1976-2016 között. Az évek során változó „szerencsével” kerültek átültetésre betegeink. Helyzetünket, sajnos - különösen a korábbi évtizedekben -, nehezítette, hogy távol vagyunk a transzplantációs centrumoktól (Budapest, Pécs), ami nem csupán transzplantációs riadó esetén jelenthetett időveszteséget, hanem a sikeres veseátültetést követő gyakori kontrollok hosszú utazásai is kimerítőek voltak betegeink számára. Ez magyarázza azt a gyakorlatot is, hogy bár kórházunk a Pécsi Egyetem Oktatókórháza, a veseátültetések túlnyomó többsége a - könnyebben elérhető - budapesti centrumban történt.

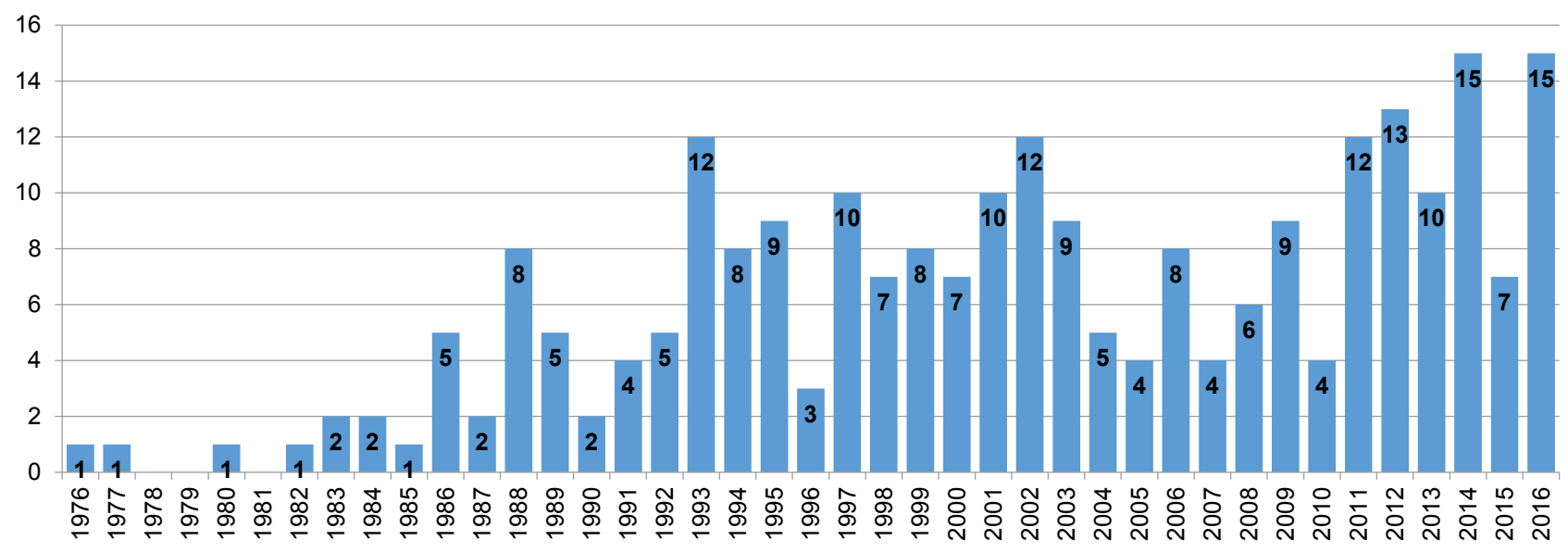

2. ábra | Vesetranszplantációk centrumunkból 1976-2016 között 


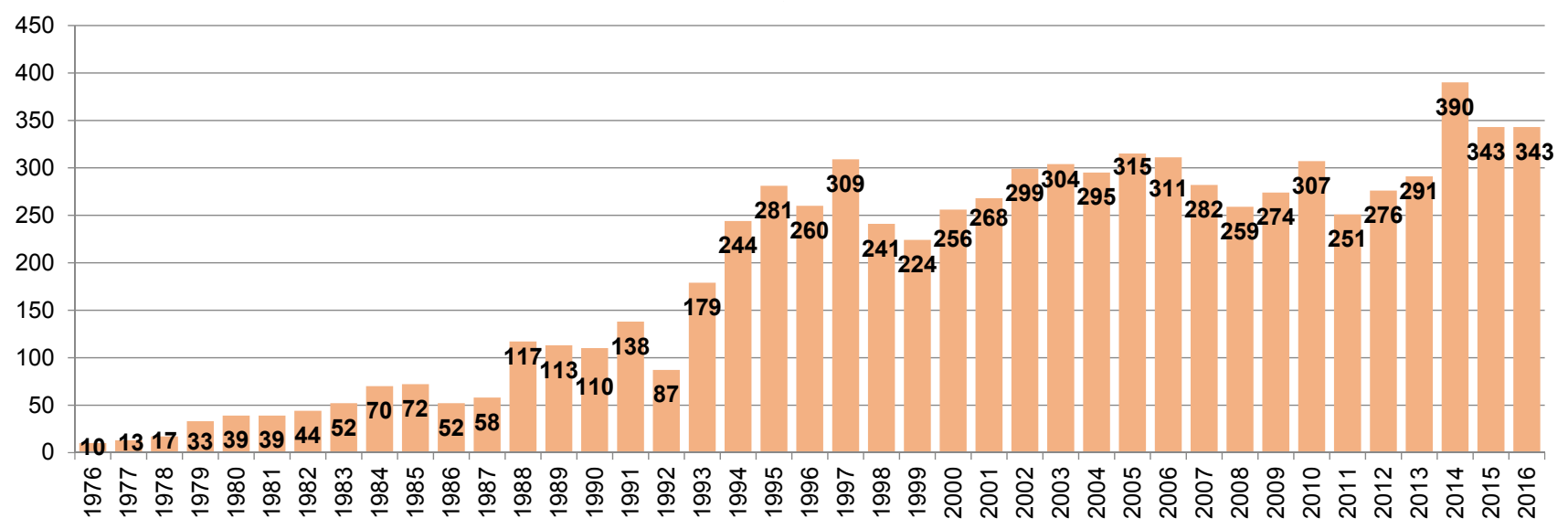

3. ábra | Vesetranszplantációk Magyarországon 1976-2016 között

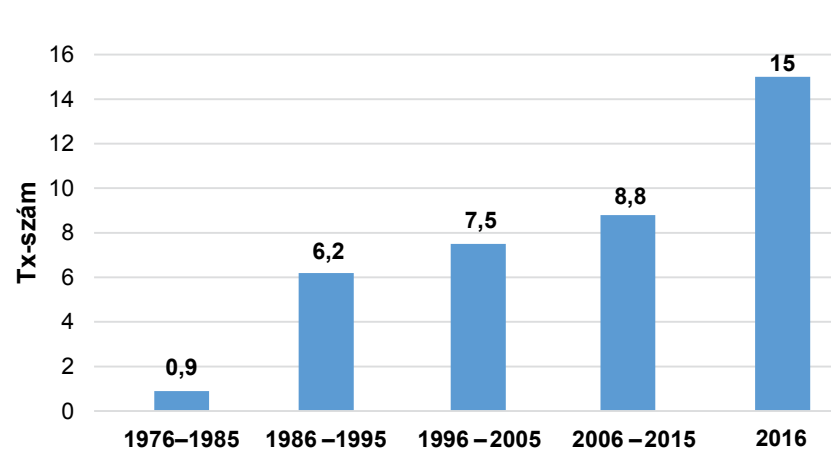

4. ábra $\quad$ Vesetranszplantációk számának átlaga centrumunkból 1976 2015 között dekádonként és 2016-ban

A 3. ábra mutatja 41 év országos vesetranszplantációs adatait. A '90-es évek közepén láthatunk egy jelentősebb növekedést, majd az újabb növekedés az Eurotranszplanthoz való csatlakozáskor (2013-tól teljes jogú tagja vagyunk) lépett fel. 2007-2016 között az országos transzplantációs átlag 301, a vasi kilenc volt, ami az öszszes eset 3\%-a. Ez megfelel Vas megye lakossági részarányának Magyarország lakosságához viszonyítva (2,6\%). Nagyobb esetszámnál kiegyenlítődnek az esélyek. A 4. ábrán évtizedes bontásban látható a szombathelyi nefrológiai centrum vesetranszplantációs átlaga.

Első vesetranszplantációjuk idején betegeink átlagosan 47,2 ( $\pm 14,0$ ) évesek voltak (a legfiatalabb 16,1 éves, a legidősebb 75,9 éves volt). Az 5. ábrán látható, hogy az utóbbi két évtizedben idősödik a vizsgált populáció: az 1976-1995 között transzplantáltak átlagéletkora 39,3 $( \pm 13,4)$ év volt, az utóbbi húsz évben 49,9 ( \pm 13,2) év.

A vizsgált periódusban veseátültetésen átesett betegeink közül 2l-nek két, három páciensnek pedig három vesetranszplantációra volt szüksége.

Vizsgálatunk legfőbb célja vesetranszplantált betegeink sorsának követése volt. A 6. ábrán látható, hogy 1976-2016 között veseátültetésen átesett betegeink $57,3 \%$-a (122/213 fó) él, az első 20 évben transzplantál-

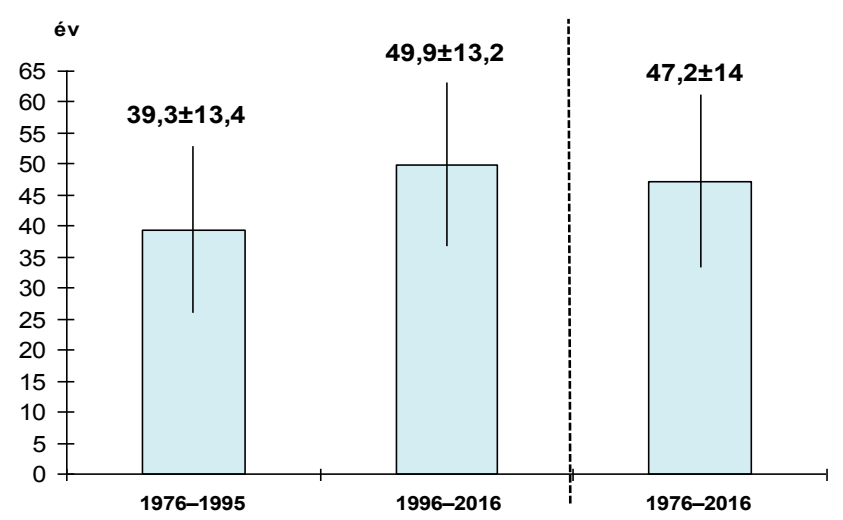

5. ábra |Átlagéletkor az első vesetranszplantáció idején

taknak is $12,5 \%$-a ( $7 / 56$ fö - van, aki közel harmincéves szervvel!). Betegeink 3,7\%-áról (8/213 fó) nincs információnk, 39\%-uk (83/213 fó) elhunyt. Összehasonlítva az első és a második 20 év vesetranszplantációs teljesítményét, 1996-2015 között két és félszeresére emelkedett a transzplantációk száma, 144 betegnél 163 veseátültetés történt szemben az első húsz év 61 transzplantációjával (56 betegnél). 1996-2016 között (21 év során) transzplantált betegeink 75,7\%-a még él. Az 1976-2016 között vesetranszplantált betegek közül $57,3 \%$ jelenleg is él (kilenc fó dialízisben, 113 múködő grafttal), közülük hét fó átültetése 1976-1995 között történt (1. táblázat). Betegeink az első vesetranszplantációt követően vesepótló kezelésben (dialízisben és transzplantált, múködő vesével) eltöltött idejét mutatja a 2. táblázat, mind a jelenleg is élö, mind a már elhunyt betegeinknél. A korábban vesetranszplantáción átesett (esetenként rejectio miatt újradializált) betegeink átlagos túlélése 10,6 év (7,2 év a múködő grafttal, továbbá 3,4 év dialízisben). A jelenleg is élő betegeink a veseátültetés óta már 8,9 $( \pm 7$ ) évet éltek átlagosan (van, aki 28,5 évet!). Volt betegünk, aki 35,1 évvel élte túl a vesetranszplantációt. 


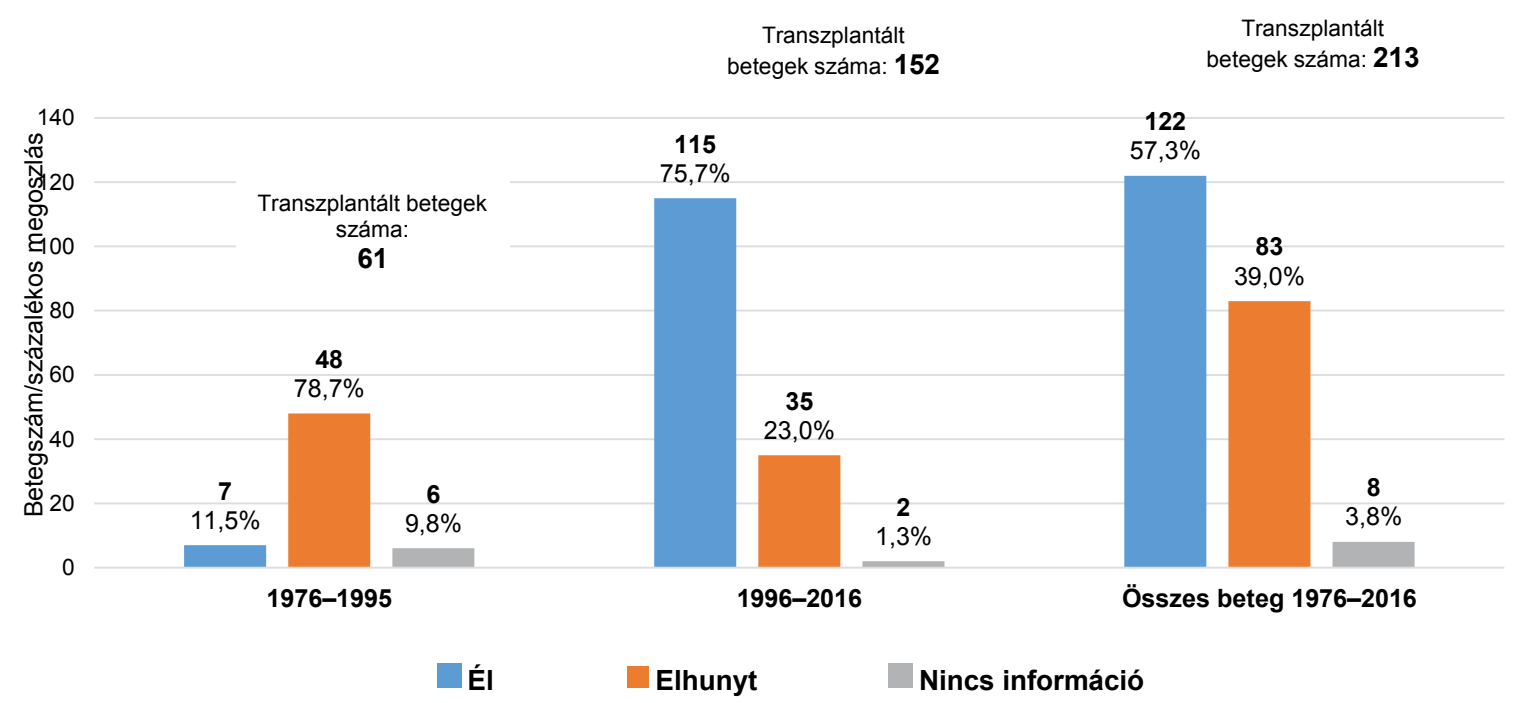

6. ábra

A transzplantált nők az első vesetranszplantáció idején fiatalabbak voltak a férfiaknál $(45,2 \pm 15,7$ év vs. 49,4 4 13,7 év), a nők túlélése a vizsgált populációban $11,2 \pm 7,4$ év a férfiak $10,3 \pm 6,6$ éves túlélésével szemben. Vesetranszplantált nőbetegeink kissé több ideig részesültek dialízisben a férfiaknál (3,7 vs. 3,2 év), az összes graftmúködésük is minimálisan hosszabb volt (7,5 vs. 7,1 év).

Az első Vas megyei élődonorból származó veseátültetés 1986-ban történt, ettől kezdve az elmúlt 30 évben

1. táblázat | Transzplantált betegeink sorsának alakulása

\begin{tabular}{l|l|l|l|l}
\hline & \multicolumn{2}{|l|}{ Jelenleg is él } & \multirow{2}{*}{ Elhunyt } & $\begin{array}{l}\text { Nincs } \\
\text { információ }\end{array}$ \\
\cline { 2 - 5 } & $\begin{array}{l}\text { Múködó } \\
\text { graft }\end{array}$ & Dializált & & \\
\hline 1976-1995 & 7 & 0 & 48 & 6 \\
\cline { 2 - 5 } $\begin{array}{l}\text { Betegek száma: } 56 \\
\text { Tx-ek száma: 61 }\end{array}$ & & & & \\
\hline $\begin{array}{l}\text { 1996-2016 } \\
\text { Betegek száma: } 152\end{array}$ & 106 & 9 & 35 & 2 \\
\cline { 2 - 5 } $\begin{array}{l}\text { Tx-ek száma: } 179 \\
\text { Összesen }\end{array}$ & & & & \\
Betegek száma: 213 & & & & \\
\cline { 2 - 5 } Tx-ek száma: 240 & & & & \\
\hline
\end{tabular}

2. táblázat | Transzplantált betegeink túlélése vesepótló kezelés (RRT) során

\begin{tabular}{llll}
\hline & Dialízisben & $\begin{array}{l}\text { Múködő graft } \\
\text { mellett }\end{array}$ & Összesen \\
\hline Jelenleg is él & $3,6 \pm 2,8$ év & $8,1 \pm 6,6$ év & $11,4 \pm 6,8$ év \\
Elhunyt & $3,4 \pm 3,1$ év & $5,9 \pm 5,4$ év & $9,3 \pm 6,9$ év \\
Összes páciens* & $3,4 \pm 2,9$ év & $7,2 \pm 6,2$ év & $10,6 \pm 6,9$ év \\
\hline
\end{tabular}

*Az ismeretlen sorsú betegek kivételével. összesen 11 fó kapott élődonortól vesét (7. ábra). A beültetett szervvel hét betegünk azóta is él. A transzplantáció idején átlag 33,8 $\pm 15,4$ évesek $(16,1-67,7)$ voltak.

Szimultán vese-hasnyálmirigy transzplantációban négy betegünk részesült, mind a négy személy él, és a beültetett szervek múködnek. (Betegeink nem részesülnek inzulinpótlásban és vesepótló kezelésben!)

2016-ban 15 vesetranszplantáció történt Vas megyéból (országos adat: $343 ; 4,4 \%$ ), egy betegünk infekciós szövődmény miatt elhunyt a posztoperatív időszakban, egy betegünknél sikertelen volt a transzplantáció (vesevéna-trombózis miatti graftvesztés okán), 13 esetben sikeres vesetranszplantáció történt (egy élőszerves és egy preemptív mútét).

\section{Megbeszélés}

A veseátültetés perioperatív mortalitása hazánkban $2 \%$ alatti, a transzplantált személyek egyéves túlélése 95\%, de még az ötéves túlélésük is $90 \%$. A vesetranszplantátumok

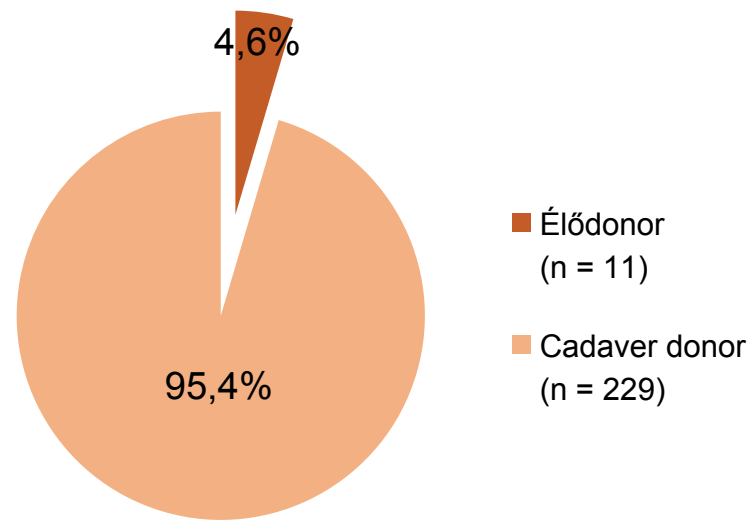

7. ábra $\mid$ A transzplantációk megoszlása a donáció szerint 1976-2016 között 
szempontjából vizsgálva, az átültetett vesék 90\%-a múködik egy évvel a beültetés után, az ötéves szervtúlélés $75 \%$, de még 10 év után is $55 \%$-a múködik a transzplantált veséknek [13]. Az ERA-EDTA regiszter adatai szerint az ötéves grafttúlélés cadaver donáció esetén 79\%, élószerves donáció esetén $87 \%$ [9]. A betegek transzplantáció utáni túlélése annál hosszabb, minél kevesebb ideig voltak a veseátültetés előtt dializáltak.

Egy korábbi adatgyújités feltárta, hogy 2014. december 31-ig Magyarországon 7203 vesét transzplantáltak, a betegek közül 3105-öt gondozott még a négy centrum, mert ők nem dializált, vesegrafttal élő páciensek voltak. (Arra nézve nem volt adatunk, hogy milyen arányban voltak köztük a többszörösen vesetranszplantált betegek [19].) A vesetranszplantációs várólistán lévő betegek átlagos várakozási ideje 2014-ben Magyarországon 3,11 év volt [20]. A várólistán lévók száma az elmúlt 11 évben ingadozó volt: 2004 végén 916, 2009-ben 668, 2013ban 1014, 2014-ben 957, 2016-ban 1075 (ebból 109 preemptív). Veseátültetés szempontjából az eddigi legsikeresebb év 2014 volt: 390 Tx történt. A megelóző 10 évben a transzplantáltak száma évi 235 és 309 között mozgott [7]. 2014-ben Magyarországon egymillió lakosra 40 vesetranszplantáció jutott, ami az előző évekhez képest jelentős aktivitásnövekedést mutatott. (Az ERA-EDTA adatai szerint 2014-ben Hollandiában 59, Ausztriában 47, Dániában, Finnországban és Svédországban 44-45, Lengyelországban 32, Szlovákiában 20 transzplantált beteg jutott egymillió lakosra.)

$\mathrm{Az}$ élővese-donáció átlaga is javult, de jelentősen elmaradt a fejlett európai országoktól (Hollandiában 53\%, Dániában $44 \%$, az adatszolgáltató muszlim többségú országokban - például Törökország, Bosznia és Hercegovina, Tunézia - 75-100\%), míg a magyar adat 2014-ben $12,3 \%$ - ezen a téren még komoly fejlődést kell elérnünk $[9,21]$.

A centrumunk által végzett felméréshez hasonló magyar adatokkal nem rendelkezünk. 2011-ben Ondrik és mtsai számoltak be a MANET nagygyúlésén korábban peritonealisan dializált betegek transzplantációjáról [22].

A szombathelyi nefrológiai centrumban az utóbbi 41 évben 213 betegünknél összesen 240 vesetranszplantáció történt (6. ábra). 113 betegünk jelenleg is múködő vesegrafttal él $(53 \%)$, kilenc betegünknél graftrejectio miatt dialízis zajlik, nyolc betegról nincs információnk, 83 fó elhunyt (39\%). 213 vesetranszplantált betegünk közül 122 fó $(57,3 \%)$ jelenleg is biztosan él, $113(53 \%)$ a beültetett, múködő szervvel!

A dializáltak prevalenciája megyénkben 2016 végén egymillió lakosra vetítve 921 , az átültetett vesével élóké 446 volt, azaz az összes vesepótló kezelésben részesülő betegek aránya megyénkben 2016 végén egymillió lakosra számolva (per million people - pmp) 1367 fó volt. Országos összehasonlító adataink 2014 végéról vannak, akkor a vesepótló kezelésben (renal replacement therapy - RRT) részesülő betegek prevalenciája Vas megyében

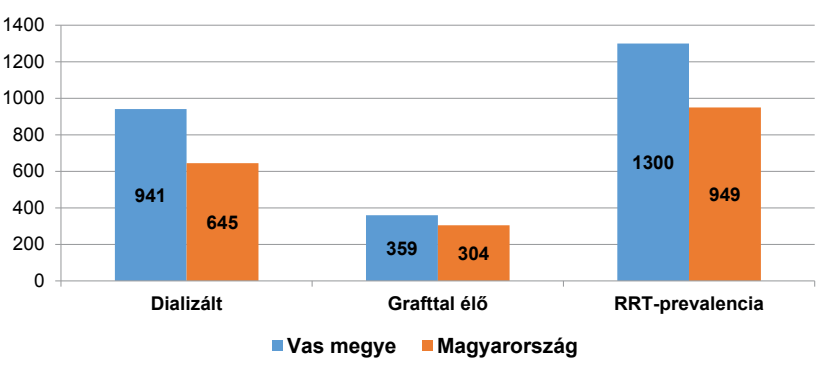

8. ábra $\quad$ Vesepótló kezelésen lévő betegek prevalenciája egymillió lakosra Vas megyében és Magyarországon 2014 végén

1300 pmp volt, míg a magyarországi átlag ennél alacsonyabb, 949 pmp volt (8. ábra).

Budapesten már 1974-tốl volt lehetőség élődonoros veseátültetésre, évi kettô-nyolc ilyen mútét történt, 2005 után már évi tíz feletti mútétszámmal. Pécsett 1998-tól ültetnek be évi kettő-hatot ezen a módon, Szegeden 2006-ban indultak három-öt átültetéssel, és 2010 óta Debrecenben is elérhetővé vált az élődonoros veseátültetés. Az országos 10\%-os arány azonban elmarad a nyugat-európai közel 20\%-os átlagtól, ső́t a skandináv országokban ez 40\% körüli, miként az Amerikai Egyesült Államokban is. Ezek az arányok leginkább a nem genetikai rokonok közötti transzplantációknak köszönhetők. Elsősorban a házastársak közötti eredmények olyan biztatóak, hogy az immunológiai egyezés a modern immunszuppresszió mellett gyakorlatilag elhanyagolható. Ez a lehetőség hazánkban is adott, etikai bizottság elött kell ilyenkor megjelenni, amely meggyőződik arról, hogy nincsen anyagi érdekeltség a donor és a recipiens között (különös tekintettel az úgynevezett „érzelmi rokonok” közötti átültetésnél merül fel a lehetősége) [23].

Bár az utóbbi 10 évben centrumunkból transzplantált betegeink száma fokozatosan nőtt, minimális volt az élődonoros Tx (4,6\%). Az élődonoros vesetranszplantáció egyértelmú előnye a lényegesen kevesebb akut rejectio ( $46 \%$ vs. cadaver szervnél $62 \%$ az Amerikai Egyesült Államok adatai alapján), és alig van megkésett indulású transzplantátum ( $5 \%$ vs. $19 \%$ ), ami a rövid „hideg ischaemiás időnek" és - rokonból történő donáció esetén jobb HLA-azonosságnak tudható be [13]. Magyarországon 2012-ben volt a legtöbb élődonorból történő veseátültetés, 53 esetben (19,2\%-a az összes vesetranszplantációnak), 2014-ben 12,3\%-a, 2015-ben 11,7\%-a, 2016-ban a vesetranszplantációk 9,9\%-a volt donáció eredménye [18].

Az utóbbi évtizedben folyamatosan növekvő számban transzplantált betegeink között minimális volt az élődonoros veseátültetés aránya. Az RRT-n lévő betegek zömét még mindig a dializáltak jelentik. Nagyon idős populációt kezelünk, dializált betegeink átlagéletkora 2016 végén 67,1 év volt. Betegeink igen jelentős arányú komorbiditása is nehezíti a transzplantációs várólistára kerülést (a Charlson-index a hemodializáltak között átlagosan 8,1 , a peritonealis dialízist végzók körében 5,5 , a 
teljes dializált populációra számítva 7,5 volt). A vesetranszplantációs várólistán 2016. december 31-én 22 HD-s és kilenc PD-s betegünk, továbbá négy predializált páciensünk volt. A kivizsgálásba minden beteg beleegyezett, ezért a bővülés lehetőségét a predializált betegek nagyobb arányú bevonásában és az élőszerves donáció további népszerüsítésében látjuk.

A transzplantált betegek gondozásának problémái:

- Tekintettel arra, hogy az élő, gondozott vesetranszplantáltak száma jelenleg 3200-3300 före tehető (és további növekedésük várható a mưtétszám és a túlélés javulásával), a transzplantációs klinikáknak és osztályoknak a veseátültetést követő stabilizációt követően (három-hat hónap után), véleményünk szerint, meg kellene osztaniuk a megyei nefrológiai centrumokkal a beteggondozás feladatait, hogy ezáltal a túlterhelt csúcsintézmények fellélegezhessenek.

- A megyei nefrológiai szakellátásban ellátott betegek számára jelentős könnyebbséget jelent a kisebb távon történő, ezáltal kevésbé fárasztó és financiálisan is kedvezőbb utaztatás. Kisebb beteglétszám mellett hamarabb juthatnak a betegek gyógyszereikhez, beszélhetik meg az őket már régóta ismerő nefrológussal problémáikat, állapotváltozásukat.

- A stabil állapotú vesetranszplantált betegek ellátásához elérhetővé kell tenni a helyi laboratóriumokban az immunszuppresszív terápia gyógyszerszintjeinek monitorizálását, mind labordiagnosztikai, mind finanszírozási hátteret társítva hozzá.

- Jelenleg infekciós szövődmény, heveny állapotrosszabbodás esetén a transzplantált beteg a megyei sürgősségi ellátásban jelenik meg, rendszeresen a megyei kórházakba veszik fel óket, és a transzplantációs centrumok fekvőbeteg-kapacitásának szúkössége okán tartósan a megyei kórházak kezelik óket. Ilyenkor telefonon konzultálni kell a transzplantációs klinikák és osztályok nefrológusaival, hogy helyben kezelhetőek-e tovább vagy át kell helyezni őket a transzplantációs centrumba.

- Jónak tartanánk egy útmutatást azokra az esetekre, hogy amikor krónikus rejectio miatt dialízisre kerül a beteg, meddig tartson az immunszuppresszív terápia, kivegyék-e egyáltalán és mikor a nem múködő graftot.

- Szükség lenne a Vesetranszplantált Betegek Regiszterének felállítására. Ebben szerepelhetnének:

- az immunológiai egyezések a mütétkor,

- az immunszuppresszív kezelés formái,

- a rövid és hosszú távú szövődmények (daganatos, cardiovascularis, illetve sebészeti szövődmények, immunszuppresszív kezelésekhez társuló infekciók tekintetében),

- mennyi a grafttúlélés,

- a dialízisbe való visszakerülés,

- a halálozás okai.
Anyagi támogatás: A közlemény megírása, illetve a kapcsolódó kutatómunka anyagi támogatásban nem részesült.

Szerzôi munkamegosztás: D. A., K. I.: Hipotézisek kidolgozása. D. A., M. E., R. E., Sz. Gy.: A vizsgálat lefolytatása, adatgyưjtés. D. A., M. E., K. I.: Statisztikai elemzések. D. A., K. I.: A kézirat megszövegezése. A cikk végleges változatát valamennyi szerző elolvasta és jóváhagyta.

Érdekeltségek: A szerzőknek nincsenek érdekeltségeik.

\section{Irodalom}

[1] KDIGO 2012 clinical practice guideline for the evaluation and management of chronic kidney disease. Kidney Int Suppl. 2013; 3: $1-150$.

[2] Ministry of National Resources. Vocational Guideline for Health Care - Recognition and stratification of chronic renal disease in the adulthood with examination of the estimated GFR and proteinuria. [NEFMI Szakmai Kollégium. Egészségügyi Szakmai Irányelv - A felnőttkori idült vesebetegség felismerése és beosztása a számított GFR és a fehérjevizelés vizsgálatával.] 2014. 02. 28. [Hungarian]

[3] Levey AS, Stevens LA, Schmid CH, et al. A new equation to estimate glomerular filtration rate. Ann Intern Med. 2009; 150: 604-612.

[4] Nagy J. The chronic kidney disease "epidemy". [Krónikus vesebetegségek „epidémiája”.] Orv Hetil. 2013; 154: 43-51. [Hungarian]

[5] United States Renal Data Systems (USRDS). Annual Data Reports 2014. Available from: www.usrds.org

[6] 6th Hungarian Cardiovascular Consensus Conference. [VI. Magyar Kardiovaszkuláris Konszenzuskonferencia.] 2014. november 28. [Hungarian]

[7] Kulcsár I. Epidemiology of chronic renal disease and dialyzed patients. [A krónikus vesebetegek és a dializált betegek epidemiológiája.] Hypertonia és Nephrologia 2015; 19 (Suppl 3): 4-7. [Hungarian]

[8] Fresenius Medical Care. ESRD patients in 2013. A Global perspective. Available from: http://www.fmc-ag.com

[9] ERA-EDTA Registry. Available from: https://www.era-edtareg.org/files/annualreports

[10] Kulcsár I, Illés M, Kovács L. Dialysis treatments in Hungary 2010-2015. [Dialíziskezelés Magyarországon 2010-2015.] Hypertonia és Nephrologia 2016; 20: 208-212. [Hungarian]

[11] Kulcsár I, Illés M. Hungarian Society of Nephrology Dialysis Registry 2016. [MANET Dialízis Regiszter 2016.] (Under publication)

[12] Szelestei T, Remport Á, Gergely L. Actual issues of transplantation. [A transzplantáció aktuális kérdései.] Hypertonia és Nephrologia 2011; 15(Suppl 2): 31-34. [Hungarian]

[13] Szederkényi E. Renal transplantation. [Vesetranszplantáció.] Transzplantációs Továbbképző Szemle 10-13. [Hungarian]

[14] Németh A, Petri G, Gál Gy, et al. Renal homotransplantation in two brothers. [Vese-homotransplantatio két testvér között.] Orv Hetil. 1963; 104: 2017-2024. [Hungarian]

[15] Kiss É, Gál Gy. Surpassing persons of the Hungarian nephrology: Németh András (1924-1999). [A magyar nefrológia kiemelkedő alakjai: Németh András (1924-1999).] Hypertonia és Nephrologia 2013; 17: 149-152. [Hungarian] 
[16] Petri G. Renal transplantation - History. In: Balogh F, Petrányi Gy, Rényi-Vámos F. (eds.) Nephrology - Diseases of the kidney. [Veseátültetés - Történeti előzmények. In: Balogh F, Petrányi Gy, Rényi-Vámos F. (szerk.) Nephrologia - A vese megbetegedései.] Medicina Könyvkiadó, Budapest, 1980; p. 446. [Hungarian]

[17] Toronyi É. The discovery and development of Sandimmun. [A Sandimmun felfedezése és továbbfejlesztése.] Hypertonia és Nephrologia 2005; 9: 19-23. [Hungarian]

[18] Hungarian National Blood Transfusion Service. Donation-transplantation Basic Data. [Országos Vérellátó Szolgálat honlapja. Donációs-transzplantációs alapadatok.] Available from: http:// www.ovsz.hu/oco/donacios-transzplantacios-alapadatok [Hungarian]

[19] Wagner L, Kalmár-Nagy K, Nemes B, et al. Epidemiology of renal transplantation in Hungary, 2014. [A vesetranszplantáció epidemiológiája Magyarországon 2014-ben.] Hypertonia és Nephrologia 2015; 19(Suppl 4): S54. [Hungarian]
[20] Hungarian National Blood Transfusion Service. Waiting List for Renal Transplantation. [Országos Vérellátó Szolgálat honlapja. Vesetranszplantációs várólista.] Available from: http://www. ovsz.hu/vese/vese-transzplantacios-varolista [Hungarian]

[21] Eurotransplant. Eurotransplant Statistics Report Library. Available: http://statistics.eurotransplant.org

[22] Ondrik Z, et al. What do we know about the faith of patients transplanted from peritoneal dialysis. [Mit tudunk a transzplantált PD-betegek sorsáról?] Hypertonia és Nephrologia 2011; 15(Suppl 1): S63. [Hungarian]

[23] Langer R, Toronyi É. Status of renal transplantation in Hungary, 2010. [A vesetranszplantáció helyzete Magyarországon, 2010.] Hypertonia és Nephrologia 2010; 14: 243-246. [Hungarian]

(Dobos András dr., Szombathely, Hübner János utca 1-3., 9700
e-mail: butcher.md@gmail.com) Szombathely, Hübner János utca 1-3., 9700
e-mail: butcher.md@gmail.com)

\section{NOTA}

\section{Új fejlesztés az egészségügyben dolgozók, tanulók részére!}

A magyar nyelvứ szakirodalmi keresőszolgáltatás

\section{Mi a NOTA? \\ Napivizit Orvosi Tudástár Alkalmazás}

Mit tud a NOTA portál?

Megkönnyíti a magyar nyelvű szakirodalmi források keresését.

Eszköztöl függetlenül, akár okostelefonról, a betegágy mellett állva is használható.

\section{Miben kereshet a NOTA-val?}

Az Akadémiai Kiadó folyóirataiban: Orvosi Hetilap, Magyar Sebészet, Mentálhigiéné és Pszichoszomatika.

Más kiadók magyar nyelvú szakfolyóirataiban: pl. Lege Artis Medicinae, Hypertonia és Nephrologia, Ideggyógyászati Szemle.

A hatályos szakmai irányelvekben

Magyar nyelvű kérdésekre adott ango nyelvű találatokban, a PubMeden.

\section{nota.hu}

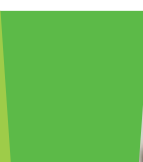

\section{Akadémiai Kiadó}

A Wolters Kluwer Csoport tagja

1117 Budapest, Prielle Kornélia u. 21-35. / Telefon: (1) 464-8246 www.akademiai.hu / www.akademiai.com

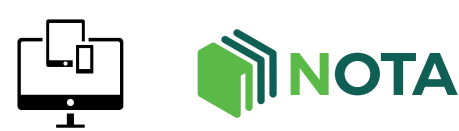

AKADÉMIAI KIADÓ 